\title{
ASSESSMENT OF THE ADAPTATION OF TOURISM SUPPLY OF CULTURAL HERITAGE OBJECTS FOR THE ELDERLY IN THE CONTEXT OF ACCESSIBLE TOURISM. CASE STUDIES FROM POLAND
}

\author{
Łukasz Szat - Weronika Terlecka - Alina Zajadacz - Aleksandra Minkwitz - Anna Lubarska \\ Faculty of Geographical and Geological Sciences, Adam Mickiewicz University in Poznan, \\ Poland; alina.zajadacz@amu.edu.pl
}

DOI: $10.15170 / T V T .2021 .06 .03 .08$.

\begin{abstract}
The aim of the research was to define the criteria for assessing the availability of tourist attractions for elderly people and to check the adaptation of tourist attractions in terms of these requirements on a selected example. Testing the developed criteria in selected facilities allowed for their verification, taking into account the opinions of older people. Consequently, the developed criteria for assessing the availability of tourist attractions for the elderly have become the basis for the preparation of an audit covering cultural heritage sites that are part of one of the historically oldest tourist routes in Poland (the Piast Route). The article presents the results of the research in the methodological aspect, including the catalog of criteria for assessing the availability of tourist attractions for the elderly, as well as in the cognitive aspect, the results of the audit carried out on the basis of this catalog in 2019 in 32 facilities located in the Greater Poland part of the Piast Trail. These results provide the basis for a comprehensive assessment of the adaptation of tourist attractions to the needs of the elderly. They also show the status of meeting the requirements in this respect in selected facilities. In addition, the final conclusions may become a starting point for further research, including, in addition to cultural attractions, also diverse natural tourist attractions.
\end{abstract}

Keywords: accessible tourism, tourism supply, tourism atractions, tourist attraction, cultural heritage 


\begin{abstract}
Absztrakt
A kutatás célja az volt, hogy felmérje, a turisztikai vonzerők idősek számára való hozzáférhetővé tételének mik a feltételei, illetve hogy egy kiválasztott példán keresztül megvizsgálja, mennyire alkalmazkodnak a turisztikai vonzerők ezekhez a feltételekhez. A megfogalmazott kritériumok kiválasztott létesítményeknél történő tesztelése lehetővé tette azok igazolását, figyelembe véve idős emberek véleményét is. Ennek köszönhetően a turisztikai vonzerők idősek számára való hozzáférhetővé tételére kidolgozott feltételek alapján egy felmérés készült, amely a történelmileg egyik legrégibb lengyelországi turistaút (a Piast Út) kulturális örökség helyszíneire terjedt ki. A tanulmány a kutatás eredményeit mutatja be módszertani szempontból, benne a vonzerőket idősek számára elérhetővé tevő feltételek tételes felsorolását, valamint a kognitív szempontokat, az említett feltétel-lista alapján 2019-ben 32, a Piast Útnak a nagy-lengyelország régióbeli helyszínein végzett felmérés eredményeit. Ezen eredmények alapján széles körüen felmérhető, hogy az egyes turisztikai vonzerők mennyire igyekeznek megfelelni az idős utazók igényeinek. Az is láthatóvá válik, hogy a kiválasztott létesítmények jelen állapotukban mennyire felelnek meg ezeknek a feltételeknek. Ezen túl a levont következtetések további kutatások alapjául szolgálhatnak, amelyek a kulturális vonzerők mellett a különböző természeti vonzerőkre is kiterjedhetnek.
\end{abstract}

Kulcsszavak: akadálymentes turizmus, turisztikai kínálat, turisztikai vonzerök, kulturális örökség 


\section{Introduction}

The ongoing and projected demographic changes related to the aging of the population affect many areas, including tourism. Issues related to access to this type of recreation for the elderly are becoming more and more important. The individual needs of seniors, but also other groups that require various types of adaptation, are met by accessible tourism. According to its concept, emphasis is placed on designing tourism spaces in a universal manner, taking into account the determinants of tourism activity of many groups (ZAJADACZ - STROIK 2016). Accessible tourism is both a human right and a business opportunity" (UNWTO 2018). ${ }^{11}$

In the case of an attempt to assess the adaptation of tourist attractions in terms of these needs, the selection of evaluation criteria becomes of key importance. The problem of their determination is related to both the heterogeneous nature of the group of seniors and tourist attractions. This makes it necessary to develop a list of evaluation criteria adequate to the specificity of the assessed attractions and taking into account a wide spectrum of the needs of elderly people.

The aim of the research was to define the criteria for assessing the availability of tourist attractions for elderly people and to check the adaptation of tourist attractions in terms of these requirements on a selected example. Testing the developed criteria in selected facilities allowed for their verification, taking into account the opinions of older people. As a result, the developed criteria for assessing the availability of tourist attractions for the elderly have become the basis for the preparation of an audit covering cultural heritage sites that are part of one of the historically oldest tourist routes in Poland (the Piast Route).

\section{The review of the literature}

The number of people over the age of sixty surpassed the number of people under the age of five in the world for the first time in 2000, which indicates that even in countries with high natural increase, the population is aging (VIGOLO 2017). In the European Union alone, the elderly (between 55 and 80 years old) account for about $25 \%$ of the population (RAPORT 2012). In 2060, as many as $12 \%$ of the world's population will be people over 80 , and $29 \%$ - people over 65 (TRACZ - DRAL 2019). The quoted data, in addition to confirming the already visible demographic trend, show a diverse approach to the age limit from which we can talk about older people, as well as heterogeneity within their group.

Due to a number of factors, there are currently two main groups of elderly people, the so-called The Silent Generation, born 1925-1945 and Baby Boomers born 1946-1964 as children of the postwar baby boomers. The oldest representatives of the first group are now over 90 years old, while the second group is not only younger, but to a large extent also more agile, wealthier, better educated, they have a greater desire for novelty and authentic experiences than previous generations of retirees (LEHTO et al. 2008, PATTERSON - PEGG 2009, VIGOLO 2017). The group of seniors is diverse not only in terms of physical functioning, but also intellectual performance (MARCINEK 2007).

From the perspective of the tourism industry, seniors constitute a difficult group of potential travelers, also due to their tourist choices, which is facilitated by the fact that they rely on their own previous experiences, their own searches (in the press or new media), or on the recommendation of friends. Nevertheless, it has great potential (DANN 2002). According to JOANNA ŚNIADEK (2006), the main reasons why this group may be attractive for the tourism industry include: (1) the unusual dynamics of growth of the seniors market; (2) a large amount of free time to be managed;

\footnotetext{
${ }^{11}$ Messages of the World Committee on Tourism Ethics on Accessible Tourism http://cf.cdn.unwto.org/sites/all/files/docpdf/wctemessagesonaccessibletourism.pdf.
} 
(3) relatively high wealth and purchasing power; (4) willingness to maintain good health and physical condition, which is what tourism is for; (5) willingness to reward oneself for a life of sacrifice, turning to self-development and self-pleasure; (6) willingness to travel outside the tourist season; (7) social reasons.

In response to the occurring and forecasted demographic changes, Polish authors take up a number of issues related to the tourist movement of older people, most often in connection and with examples of specific tourism spaces, e.g. selected cities, national parks or health resorts. So far, the followig issues have become the subject of interest of researchers and theorists:

- rules for safe tourism in old age: indications and contraindications for tourism proposed by Łobożewicz (ŁOBOŻEWICZ 2000), Pilis rules (2010) based on LANG's guidelines (1974);

- factors influencing the tourist activity of seniors (GŁĄBIŃSKI 2020, GŁĄBIŃSKI 2018);

- forms of tourist activity most often undertaken by seniors (KUPRJANOWICZ 2005; ŁOBOŻEWICZ 2000) and their tourist preferences (GÓRNA 2015)

- reasons for the elderly taking up tourist activity in Polish national parks and the forms it takes (PRÓSZYŃSKA-BORDAS 2013)

- free time of seniors (GOSIK 2017, RZEPKO et al. 2017).

As part of the last of the discussed issues, it is worth mentioning the very up-to-date research related to the topic of free time behavior and the changes brought about by the Covid-19 pandemic. In the qualitative survey conducted in December 2020 on a group of 71 residents of the largest Polish cities, respondents aged over 50 accounted for approx. 44\% (31 people). Changes in this area were tracked on the basis of interviews based on an extensive questionnaire and completed by the participants of the weekly self-report sheets of leisure activities. The structure of the questions asked during the study made it possible to answer the question of how the pandemic influenced not only the daily rest of the elderly, but also the decisions to spend free time away from home during weekends and in the summer (ZAJADACZ 2021) ${ }^{12}$.

From the perspective of these considerations, however, the most important publications concern the adaptation of the tourist offer to the needs of older people. It is therefore worth mentioning the research conducted by the Ministry of Sport and Tourism (2011) and ZAWADKA (2016), concerning the importance of amenities in accommodation establishments. In the study of the 2011 study, it was found that as many as $82 \%$ of respondents indicated a bathroom in a room as the most needed facility in this type of facility, $68 \%$ of respondents opted for full board, and health care was chosen by $67 \%$ of respondents (the questionnaire allowed for more than one answer to question posed). The bicycle rental (44\%), facilities for people with mobility impairments (42\%), airconditioning in the room (42\%), restaurant / bar (41\%), and an elevator (39\%) were also considered important from the point of view of a senior citizen. On the other hand, in the study conducted by ZAWADKA (2016), in which the respondents chose only one facility necessary from their point of view, more than half of the responses $(55.5 \%)$ indicated a bathroom in the room, $18 \%$ full board, and $12.5 \%$ health care. Other amenities important for seniors also remained broadly consistent with the findings of the previous study and included, among others: elevators (12.1\%), accessibility of public transport (10.4\%), air conditioning (8.5\%), availability of recreational equipment (6.1\%), the Internet $(5.8 \%)$ and facilities for people with disabilities $(5.5 \%)$.

Amenities in accommodation facilities are certainly an important aspect related to the decisionmaking by older people about departure and its quality. However, the needs of older people should

12 The research was financed by the grant "Research on COVID-19" from the funds of the University of Adam Mickiewicz in Poznan for the years 2020-2021, grant manager: Alina Zajadacz. 
also be taken into account in other tourism spaces. A rational response to the ongoing and forecasted demographic changes are therefore activities related to the so-called "accessible tourism" (ZAJADACZ - STROIK 2016), which replaced the concept of "tourism for all", popular a decade ago (ZAJADACZ 2014). While in the above-mentioned studies on amenities in hotel facilities, they mainly concerned the sphere of the comfort of older people, affecting the elimination of possible physical and technical barriers, accessibility in cultural heritage facilities is understood much more broadly. It refers to both the place (location), but also the availability of information, social relations, the possibility of achieving the activity goal (ZAJADACZ 2014). Activities undertaken as part of accessible tourism are therefore aimed at preventing structural, physical and functional limitations related to the organization of tourist services (ZAJADACZ - STROIK 2016; FARKAS - PETYKÓ 2020, GONDA - RAFFAY 2021, RAFFAY - DANYI - ERNSZT 2021, MÁTÉ 2021).

\section{Stages and Research Methods}

The desk research method was used in the first stage of the research. The criteria for accessibility of tourist attractions for the elderly were reviewed based on such studies as: Visit England (2014). National Accessible Scheme For Serviced, Self-Catering, Hostel and Campus Accommodation); Visit England (2019), National Accessible Scheme For Holiday, Touring \& Camping Parks and Caravan Holiday Homes; 'Fantastic for families' (2018), Atendo (2018) and the Regulation of the Minister of Infrastructure of April 12, 2002 on the technical conditions to be met by buildings and their location. On the basis of a review of the developed requirements for the adaptation of tourist facilities for the elderly, a preliminary catalog of accessibility criteria was developed

The second stage included testing and verification of the proposed initial catalog of criteria for assessing the accessibility of the Piast Trail, which took place in October 2018 in eight selected sites, such as: Archaeological Museum in Poznań, Models of Old Poznań, Cathedral Basilica of Saints Peter and Paul in Poznań, Reserve Archaeological Genius Loci, Poznań Gate ICHOT, Pobiedziska Castle, the Museum of the First Piasts in Lednica and the Museum of the Origins of the Polish State in Gniezno. Representatives of the elderly (3 people aged 70-74) were involved in modifying the catalog of accessibility assessment criteria. The result of this stage was a verified catalog of criteria, which was used to conduct an accessibility audit on the selected route (Tab. 1.).

In the fourth stage the research was carried out in cultural heritage sites located on the Piast Trail, the attractions of which refer to the beginnings of Polish statehood. Its area has been narrowed down to all the facilities in the Greater Poland part of the route running through two voivodeships (the other is the Kuyavian-Pomeranian Voivodeship), managed by the Piast Trail tourist cluster in Greater Poland. Thus, it concerned 32 objects that can be divided into the following groups:

- 11 sacred buildings (Basilica of the Assumption of the Blessed Virgin Mary and St. Michael the Archangel in Trzemeszno, Cathedral in Gniezno, Poznań Cathedral, St. Nicholas the Bishop Parish Church in Tarnów Pałucki, St. Nicholas the Bishop Cathedral in Kalisz, St. John of Jerusalem Outside the Walls in Poznań, the Franciscan Church in Gniezno, the Church of St. John the Baptist in Gniezno, the Church of the Assumption of the Blessed Virgin Mary and St. Nicholas in Giecz, the Benedictine Abbey in Lubin, the complex of the former Cistercian Abbey in Wągrowiec, the former Cistercian abbey in Ląd on the Warta River);

- 7 museums (the Archaeological Museum in Poznań, the Museum of the Archdiocese of Gniezno, the Museum of the Origins of the Polish State in Gniezno, the Museum of the First Piasts in Lednica, the Regional Museum in Wagrowiec, the Museum of Applied Arts in Poznań, a branch of the National Museum in Poznań, the Museum of the Pyzdry Land in Pyzdry); 
- 5 reserves or archaeological sites (Archaeological Reserve Gród Wczesnopiastowski in Giecz, Archaeological Reserve Gród in Grzybowo, Archaeological Reserve in KaliszZawodzie, Archaeological Reserve Genius loci, Archaeological Site Łekno,

- 2 collective facilities (Royal Route in Gniezno and Ostrów Tumski in Poznań)

- other facilities, such as: The Dorotka Tower, the Interactive Center for the History of Ostrów Tumski Brama Poznania, Pobiedziska Castle, Models of Old Poznań, Open-air Museum of Miniatures of the Piast Trail or the Koniński Pole.

The study was conducted in 2019 using a proprietary questionnaire, the use of which was preceded by testing its usefulness in selected objects of the trail. The spreadsheet created in this way consisted of accessibility criteria divided into eight main categories: general requirements, expositions and exhibition space, hygiene and sanitation facilities, rest area / zones, tourist information, visitor service staff, other services and facilities, and admission tickets. The questionnaire also included questions that allowed the facility manager to perform self-evaluation.

The first area, called "general requirements", focused on the comfort of sightseeing, understood as the convenience of the equipment and the pace of sightseeing adapted to the needs of older people, the presence of seats at least every 30 meters in conditions requiring long distances, and the existence of non-slip and stable surfaces. The criteria related to the availability of the exhibition and exhibition space concerned such aspects as the possibility of visiting the facility individually and in groups with a guide and organizing events and workshops dedicated to seniors in the facility. In the area of hygienic and sanitary facilities, it was checked whether a toilet was located in the facility or its vicinity and whether it was equipped with alarm and call signaling. Rest areas / zones were also audited, where attention was paid to the availability of seats while visiting the exhibition, at viewpoints and in the lobby / reception area. Another desirable feature was that the facility had up-to-date information in print and online - including guides for the elderly, up-to-date information about the offer and amenities, and a tourist information point. The criteria for the visiting staff concerned: training of staff in servicing the elderly; the possibility of using the services of an assistant, tourist guide contact person for questions related to the availability of the facility, possible to ask by phone, via e-mail, directly at the facility) and the presence of an accessibility consultant (The category of "Other services, amenities" included in the questionnaire referred to the organization of family events and festivals, as well as the possibility of renting folding chairs or seats, also with a backrest. Moreover, the existence of reduced tickets and free entries to the facilities was verified. In the so-called "auto-evaluation" at the end of the accessibility criteria sheet, administrators were asked to answer the following questions:

1. Is the facility well adapted for sightseeing by the elderly?

2. Are the employees of the facility able to efficiently evacuate the elderly in case of emergency?

3. Are there any works planned in the coming year related to the improvement of accessibility for the elderly? If so, please specify which ones?

4. Are inquiries and comments of elderly people registered and considered? If so, what threads are raised and what actions have been taken based on them?

Auditors, whose roles were played by employees and doctoral students of the Department of Tourism and Recreation, Faculty of Geographical and Geological Sciences, Adam Mickiewicz University in Poznań, along with the assigned group of seniors, entered the questionnaire with information on the availability of facilities from the perspective of the group mentioned. They found the presence or absence of a certain feature. They could also use the auxiliary description 
space where they noted important elements related to a given criterion. The answer "not applicable" appeared in the sheet when it did not occur in the facility at all.

\section{Research Results - assessment of the accessibility of tourist attractions}

In the examined facilities, the so-called "general requirements" were first checked . According to the auditors, out of 32 facilities, as many as 30 were characterized by the comfort of visiting, which meant, among other things, that the facility had comfortable equipment or the pace of sightseeing was adjusted to the needs of elderly people (Table 1).

Table 1. Assessment of the accessibility of tourist attractions for the elderly

\begin{tabular}{|c|c|c|c|c|}
\hline Lp. & Criterion / feature & Yes & No & $\begin{array}{l}\text { not } \\
\text { applicable }\end{array}$ \\
\hline 1. & \multicolumn{4}{|l|}{ General requirements } \\
\hline 1.1. & $\begin{array}{l}\text { Sightseeing comfort (convenience of equipment, the pace of } \\
\text { sightseeing adapted to the needs of elderly people) }\end{array}$ & 30 & 2 & 0 \\
\hline 1.2. & $\begin{array}{l}\text { In conditions that require traveling long distances, there are } \\
\text { seats at least every } 30 \mathrm{~m} \text {. }\end{array}$ & 9 & 7 & 16 \\
\hline 1.3. & The surfaces in the facility are stable and non-slip. & 25 & 4 & 3 \\
\hline 1.4. & $\begin{array}{l}\text { In off-road conditions, the surfaces are stable, non-slip, and } \\
\text { maintained in a way that prevents the accumulation of water } \\
\text { and the formation of puddles. }\end{array}$ & 14 & 10 & 8 \\
\hline 2. & \multicolumn{4}{|l|}{ Exhibition, display space } \\
\hline 2.1. & Individual guided tours. & 28 & 3 & 1 \\
\hline 2.2. & Group tours with a guide. & 29 & 2 & 1 \\
\hline 2.3. & $\begin{array}{l}\text { Events, workshops for seniors (permanent, cyclical, } \\
\text { occasional, on request). }\end{array}$ & 15 & 17 & 0 \\
\hline 3. & \multicolumn{4}{|l|}{ Hygienic and sanitary facilities } \\
\hline 3.1. & Toilet in the building. & 17 & 15 & 0 \\
\hline 3.2. & Toilet adjacent to the facility. & 15 & 11 & 6 \\
\hline 3.3 . & Alarm and call signaling in the toilet. & 4 & 19 & 9 \\
\hline 4. & \multicolumn{4}{|l|}{ Rest areas / zones } \\
\hline 4.1. & $\begin{array}{l}\text { Chairs / benches / seats with a backrest during the tour of the } \\
\text { exhibition. }\end{array}$ & 20 & 10 & 2 \\
\hline 4.2. & Chairs / benches / seats with backrests at viewpoints. & 6 & 9 & 17 \\
\hline 4.3. & $\begin{array}{l}\text { In the hall, at the reception desk, there are chairs of different } \\
\text { heights for guests, some with armrests (for those sitting down } \\
\text { and standing up). }\end{array}$ & 2 & 12 & 18 \\
\hline 5. & \multicolumn{4}{|l|}{ Tourist Information } \\
\hline
\end{tabular}




\begin{tabular}{|c|c|c|c|c|}
\hline 5.1 & $\begin{array}{l}\text { Website with information about the offer and amenities for the } \\
\text { elderly. }\end{array}$ & 3 & 28 & 1 \\
\hline 5.2. & $\begin{array}{l}\text { Printed materials: plans, maps, folders, guides with an offer for } \\
\text { the elderly, information on amenities and infrastructure } \\
\text { (toilets, cloakroom, lifts, stairs, rest areas, etc.). }\end{array}$ & 2 & 29 & 1 \\
\hline 5.3. & Information point at the facility. & 18 & 13 & 1 \\
\hline 5.4. & $\begin{array}{l}\text { Ongoing update of information on the website, in mobile } \\
\text { applications. }\end{array}$ & 30 & 1 & 1 \\
\hline 6. & \multicolumn{4}{|l|}{ Staff serving visitors } \\
\hline 6.1. & Staff trained to handle elderly people (training institution). & 4 & 27 & 1 \\
\hline 6.2. & Possibility to use the services of an assistant, tourist guide. & 26 & 6 & 0 \\
\hline 6.3 . & $\begin{array}{l}\text { "Availability consultant" - a contact person for questions } \\
\text { related to the availability of the facility, possible to ask by } \\
\text { phone, via e-mail, directly at the facility. }\end{array}$ & 27 & 4 & 1 \\
\hline 7. & \multicolumn{4}{|l|}{ Other services, facilities } \\
\hline 7.1. & Parties, family festivities. & 25 & 7 & 0 \\
\hline 7.2. & Folding chairs and seats available for hire with backrest. & 7 & 23 & 2 \\
\hline 8. & \multicolumn{4}{|l|}{ Admission tickets } \\
\hline 8.1. & Discount tickets & 17 & 0 & 15 \\
\hline 8.2. & Free entries. & 29 & 2 & 1 \\
\hline \multicolumn{5}{|c|}{ AUTOEVALUATION } \\
\hline 1. & Is the facility well adapted for sightseeing by the elderly? & 29 & 3 & 0 \\
\hline 2. & $\begin{array}{l}\text { Are the employees of the facility able to efficiently evacuate } \\
\text { the elderly in an emergency? }\end{array}$ & 29 & 1 & 2 \\
\hline 3. & $\begin{array}{l}\text { Are there any related works planned in the coming year with } \\
\text { improved accessibility for the elderly? If so, please specify } \\
\text { which ones? }\end{array}$ & 7 & 24 & 1 \\
\hline 4. & $\begin{array}{l}\text { Are inquiries and comments of older people registered and } \\
\text { considered? If so, what threads are raised and what actions } \\
\text { have been taken based on them? }\end{array}$ & 4 & 27 & 1 \\
\hline & sum & 471 & 316 & 109 \\
\hline
\end{tabular}

\section{Source: Prepared by Own.}

Due to the small area of some facilities (e.g. sacred), as many as 15 of them did not apply to the criterion related to the existence of favorable conditions for traveling long distances and seats arranged along the sightseeing route. Among the remaining facilities, such conditions existed in 9 locations, while in 7 they were absent. Most of the structures (25) had stable and anti-skid surfaces, four of the surfaces were not stable, and three other surfaces (external only) this feature did not apply. Another tested criterion related to the surface in off-road conditions. Fourteen facilities had 
stable, anti-skid and well-maintained exterior surfaces that prevented water accumulation and the formation of puddles. Ten facilities did not meet these conditions, and eight could not be verified because the external infrastructure was not owned by the facility administrator.

In the second category of criteria, elements related to the exhibition and exhibition space were checked. Individual guided tours were available in 28 facilities, and group tours with a guide in 29 facilities. Individual guided tours were not possible in only 3 facilities, and group tours with a guide were not possible in 2 . One of the facilities on the trail was unavailable to visitors during the research. Slightly more than half (17) of the facilities did not run events or workshops dedicated to seniors, while 15 facilities could boast of such initiatives.

The next elements examined were related to the hygienic and sanitary facilities. In 17 facilities there was a toilet directly in the facility, and in 15 facilities there was no toilet inside the facility. Moreover, 15 facilities have a toilet in their vicinity (in other facilities or a public toilet). In 24 sites, the tourist can use the toilet inside the building or in the immediate vicinity of the visited place. Only in four of the facilities there is alarm and call signaling in the toilet, the remaining facilities do not have such a facility.

The research also paid attention to places / zones to rest. Among the examined facilities, as many as 21 had chairs, benches or seats with backrests available when visiting the exhibition, 9 sites do not have such facilities, and one facility was unavailable to visitors during the research. Out of the examined places, 17 did not have viewpoints and in other ones, with viewpoints, a tourist in 6 of them has the option of using a seat with a backrest. When analyzing all facilities with a hall or a reception desk, only two of them have chairs of different heights (some of them contain armrests, which make it easier for people who have difficulties with sitting and putting up).

The auditors were also interested in elements relating to the area of information availability. Only 3 facilities have information on the offer and amenities for the elderly on their websites. The remaining 28 sites did not include this type of information on their website, and one facility does not have a dedicated website. Only two facilities have printed materials dedicated to seniors: plans, maps, folders, guides with an offer for the elderly, information on amenities and infrastructure (toilets, cloakroom, elevators, stairs, rest areas, etc.). Out of all the objects, 19 run their own information desk, and in 13 we will not find one. As many as 30 facilities update the information on the website or mobile application regarding the facility on an ongoing basis.

Other accessibility criteria related to the visiting staff. Only four out of 32 facilities had personnel prepared to serve the elderly as part of the implementation of dedicated training. Additionally, as many as 26 facilities offered seniors the possibility of using the services of a tourist assistant or guide. The vast majority of facilities on the trail had an "accessibility consultant". As for the availability of other services and amenities for seniors, 25 out of 32 facilities hosted events and family fairs. Only 7 tested places allowed seniors to borrow folding chairs or seats (also with a backrest). As many as 28 were characterized by temporary or permanent free entry to the facility, while 17 of the surveyed facilities offered discount tickets.

As part of the self-evaluation, facility administrators were asked to answer 4 summarizing questions on the availability of facilities for the elderly. In 29 sites, it is believed that the site is well adapted to sightseeing by the elderly. In the remaining three it was found that the facilities are not sufficiently adapted to visiting by seniors. Also in 29 facilities, employees are able to efficiently evacuate the elderly in case of emergency. The owners of one facility had a different opinion, and in two facilities such a situation would be made more difficult by the lack of permanent service. Only 6 facilities declared work related to improving accessibility for older people planned for the next year. Only four sites record and consider inquiries and comments from older people. 


\section{Research discussion}

The research carried out on selected tourist attractions, both at the stage of creating a catalog of criteria for assessing their accessibility for older people, and at the stage of the audit carried out, indicate that their owners and administrators perceive older people as an important segment of the tourist market. These activities are consistent with the presented trends in the increase in the number of elderly people in modern society (VIGOLO 2017, RAPORT 2012), and also correspond to the specificity of tourism needs of this generation (ŚNIADEK 2006, LEHTO et al. 2008, PATTERSON - PEGG 2009, ŚNIADEK - ZAJADACZ 2010, GŁĄBIŃSKI 2018, GŁĄBIŃSKI 2020).

A developed catalog of criteria for assessing the availability of tourist attractions for the elderly, based on the assumptions of: Visit England (2014). National Accessible Scheme For Serviced, Self-Catering, Hostel and Campus Accommodation); Visit England (2019), National Accessible Scheme For Holiday, Touring \& Camping Parks and Caravan Holiday Homes; 'Fantastic for families' (2018), ATENDO (2018) and the Regulation of the Minister of Infrastructure of April 12, 2002 on the technical conditions to be met by buildings and their location - was confirmed in the attractions surveyed by their owners and representatives of seniors as useful and universal in making this type of assessment and sharing its results in the tourist information system. However, it is not complete. It primarily takes into account the adaptation of buildings and the displays arranged in them. In the next stage of methodological works, it should be supplemented with important features in the natural environment.

With regard to the evaluation of selected tourist attractions, it can be stated that the facilities usually guaranteed seniors the comfort of visiting and its elementary safety, due to the stable and non-slip surfaces. However, only in a few venues there were places to sit in conditions requiring visitors to travel long distances. Complications in the movement of older people could also be caused by external, technical conditions. In the vicinity of one-third of the facilities, the surfaces were unstable and slippery, favoring the formation of puddles. The vast majority of facilities were characterized by the availability of exhibition and exhibitory space for the needs of seniors. Almost in every facility it was possible to take advantage of a guide dedicated to individual or group visits. In addition, several venues hosted workshops dedicated to the elderly and events that could potentially be attractive to them. In more than half of the facilities there were toilets located inside the buildings or in their immediate vicinity. Unfortunately, only four out of 32 facilities had alarm and call signaling. Rest areas and zones were usually located between the exhibition space and the designated sightseeing route, where the tourist can use the amenities such as chairs, benches or seats with backrests. In addition, in several facilities of this type, there were also seats at viewpoints or at the entrance to the facility, where the hall or reception is located.

Importantly, the facility administrators took care of the ongoing updating of their websites. Unfortunately, the above-mentioned pages lacked information about the offer for the elderly and printed materials describing amenities and access to existing infrastructure. There were also information points for tourists in several places. In most venues, the staff serving visitors has not been trained in servicing seniors. For the most part, however, the possibility of using a tourist guide, assistant and "accessibility consultant", who is responsible for providing information in this regard, was introduced. Other services and amenities present in most of the facilities were mainly related to the organization of family events and festivals. Only a few of them, in turn, made it possible to rent folding chairs and seats (also with a backrest), which are helpful for elderly people. There are permanent free admissions in over a dozen facilities, while in others free admissions are organized on selected days. Most of the ticketed attractions also include discounted tickets for seniors.

The opinions expressed by the administrators of the facilities in the self-evaluation prove that the vast majority of them perceived their facilities as well adapted to the service of elderly people, 
taking into account also the safety requirements and the possibility of effective evacuation by the personnel available in the facilities. Only a few of them saw the need to adapt their offer to the needs of seniors, planning works related to creating additional amenities for the elderly next year.

\section{Summary}

The developed catalog of criteria for assessing the availability of tourist attractions for the elderly has been developed on the basis of many stages of work including (1) a broad review of good practices in this topic, (2) testing of the initial list of features in selected facilities with the participation of elderly people, (3) verification of the catalog, (4) conducting an audit on its basis in the tourist attractions of the brand tourist route in Greater Poland, which is the Piast Trail. The obtained results are characterized by a high degree of universality, also due to the nature of these attractions.

The objects of cultural heritage constituting the attractions of the Piast Trail in the voivodeship Greater Poland are very diverse. In addition to the still functioning sacred buildings, which also act as monuments (e.g. the cathedrals in Poznan and Gniezno), the trail also includes archaeological reserves (e.g. the Archaeological Reserve Castle in Giecz), reconstructions of buildings (Przemysł Castle) and modern and interactive exhibition facilities (Poznan Gate). The article gives examples of research both in point objects (eg the road pole in Konin) and large-area objects (eg the Archaeological Reserve in Kalisz-Zawodzie). Attractions can also be divided into outdoor (e.g. the Museum of the First Piasts in Lednica), combining the open air with buildings (Archaeological Reserve Gród in Grzybów), to buildings or part of it (e.g. the Archaeological Museum in Poznań, or the Dorotka Tower in Kalisz). Importantly, from the perspective of accessibility management and possible changes in its scope, the objects under study are also diversified in terms of the ownership structure. On the trail you will find state, local government and private entities. This is a major challenge in terms of ensuring the consistency of the trail's tourist offer and its image as a network product. In order to improve the accessibility of the facilities, both the activities of the facilities directed inwards and the organizational culture in the network of cooperation along the route are of fundamental importance.

When recommending taking actions to increase the accessibility of cultural heritage objects for senior tourists, it is proposed to draw the attention of their managers to the following aspects:

- ensuring the proper functioning of the basic hygiene and sanitary infrastructure (adapted toilets maintained in accordance with their intended use);

- guaranteeing places and zones for rest, sightseeing comfort;

- when preparing the exhibition, paying more attention to multisensory forms of information presentation (smells, tastes, sounds, touching props, Slavic cuisine);

- careful recording and consideration of feedback from visitors, taking it into account in verifying the offer;

- testing planned changes with representatives of the offer addressees;

- developing a set of good practices from individual facilities on the trail, the purpose of which would be to share knowledge and facilitate effective actions related to the improvement of accessibility;

- drawing attention to the problem of current updating of data on accessibility on the home pages of objects - this type of "bookmarks" should be exported to websites of organizations and institutions promoting the trail as a whole. 
In addition, it is also worth paying attention to the need to organize training for the management of facilities, as well as for the staff directly serving guests. Acquiring new skills and social competences in the field of "accessible tourism" would certainly not remain indifferent to the quality of visiting facilities by seniors.

The developed system is to guarantee the topicality and reliability of information generated "from below" at the level of facility administrators and consistency by creating guidelines, monitoring and evaluating the effects "from above" by institutions promoting the trail. Therefore, further audits on the availability of facilities should also be considered.

The conducted analysis of the accessibility of objects with the rank of cultural heritage showed unequivocally that among the examined attractions there were no places completely inaccessible from the point of view of the needs of the group under consideration. This conclusion may be a starting point for further considerations and scientific research related to comprehensive management of the quality of services offered in such facilities.

\section{References}

ALÉN, E. - DOMÍNGUEZ, T. - NIEVES, L. (2012): "New Opportunities for the Tourism Market: Senior Tourism and Accessible Tourism", Visions for Global Tourism Industry - Creating and Sustaining Competitive Strategies, InTech, available at: https://doi.org/10.5772/38092.

ATENDO (2021): available at: www.spain.info

DANN, G. M. S. (2002): "Journal of Hospitality \& Leisure Senior Tourism and Quality of Life", Journal of Hospitality \& Leisure Marketing, Vol. 9 No. 1-2, pp. 5-19.

Europe, the best destination for seniors" "Facilitating cooperation mechanisms to increase senior tourist's travels within Europe and from third countries in the low and medium seasons" - Experts draft report Annex 1, (2014), available at: https://ec.europa.eu/docsroom/documents/6924?locale=pl

'Fantastic for families' (2018): available at: http://www.britishtheatreguide.info/news/fantasticfor-families-awards

FARKAS, J. - PETYKÓ CS. (2020): A FOGYATÉKOSSÁG, AZ AKADÁLYMENTESSÉG ÉS A MOBILITÁS, MINT EGZISZTENCIÁLIS ALAPTULAJDONSÁG. Turisztikai és Vidékfejlesztési Tanulmányok 2020 V. évfolyam 4. szám, pp. 43-55.

GŁĄBIŃSKI, Z. (2020): “Czynniki wpływające na aktywność turystyczna polskich seniorów w świetle opinii stuchaczy uniwersytetów trzeciego wieku". Bogucki Wydawnictwo Naukowe, Poznań.

GŁĄBIŃSKI, Z. (2018): “Uwarunkowania aktywności turystycznej seniorów przyjeżdżających do Innsbrucka, Krakowa i Szczecina”, Turystyka kulturowa, No. 4, pp. 46-62.

GOSIK, B. (2015): "Formy spędzania czasu wolnego starszych osób w województwie łódzkim", Space - Society - Economy, Vol. 14, pp. 137-149, available at: https://doi.org/10.18778/17333180.14.08

GONDA, T. - RAFFAY Z. (2021): A FOGYATÉKOSSÁGGAL ÉLÖK UTAZÁSI SZOKÁSAI. Turisztikai és Vidékfejlesztési Tanulmányok 2021 VI. évfolyam 1. szám, pp. 20-37.

GÓRNA, J. (2015): "Preferencje i aktywność turystyczna Polaków w wieku 50+“, Prace Naukowe Akademii im. Jana Długosza w Częstochowie, Vol. 14 No. 1, pp. 153-156. 
KOCISZEWSKI, P. (2016), "Turystyka seniorów jako istotny czynnik aktywizacji osób starszych", Zeszyty Naukowe Uczelnia Vistula, Vol. 46 No. 1, pp. 217-237.

KUPRJANOWICZ, B. (2005), "Rekreacja ruchowa i turystyka osób starszych", in Midura, F. and Żbikowski, J. (Eds.), Krajoznawstwo i Turystyka Osób Niepełnosprawnych, Biała Podlaska, pp. 201-211.

LANG, E. (1974): "Welches körperliche Training ist im Alter angezeigt und vertretbar?", Zeitschrift Für Bäder Und Klimaheilkunde, Vol. 21, pp. 230-234.

LEHTO, X. Y. - JANG, S. C. (SHAWN) - ACHANA, F. T. - O'LEARY, J. T. (2008): "Exploring tourism experience sought: A cohort comparison of Baby Boomers and the Silent Generation", Journal of Vacation Marketing, Vol. 14 No. 3, pp. 237-252.

ŁOBOŻEWICZ, T. (2000): “Turystyka ludzi w starszym wieku”, Turystyka i Rekreacja Ludzi Niepetnosprawnych1, pp. 219-256.

MÁTÉ, A. (2021): AZ AKADÁLYMENTES TURIZMUS LEHETŐSÉGEI EGY HELYTÖRTÉNETI MÚZEUM PÉLDÁJÁN. Turisztikai és Vidékfejlesztési Tanulmányok 2021 VI. évfolyam 1. szám, pp. 39-56

NIMROD, G. (2008): "Retirement and tourism Themes in retirees' narratives", Annals of Tourism Research, Elsevier Ltd, Vol. 35 No. 4, pp. 859-878.

NIMROD, G. AND ROTEM, A. (2010): "Between relaxation and excitement: Activities and benefits gained in retirees' tourism”, International Journal of Tourism Research, Vol. 12 No. 1, pp. 65-78.

PATTERSON, I. - PAN, R. (2007): "The Motivations of Baby Boomers to Participate in Adventure Tourism and the Implications for Adventure Tour Providers", Annals of Leisure Research, Vol. 10 No. 1, pp. 26-53.

PATTERSON, I. - PEGG, S. (2009): "Marketing the leisure experience to baby boomers and older tourists", Journal of Hospitality and Leisure Marketing, Vol. 18 No. 2-3, pp. 254-272.

PEARCE, P. L. (1999): “Touring for Pleasure: Studies of the Senior Self-Drive Travel Market”, Tourism Recreation Research, Vol. 24 No. 1, pp. 35-42.

PILIS, A. - PILIS, K. - PILIS, W. (2010): "Rola turystyki w życiu ludzi starszych", Prace Naukowe Akademii Im. Jana Dtugosza w Częstochowie, Vol. 9.

RAFFAY-DANYI, Á. - ERNSZT, I. (2021): ESÉLYEGYENLŐSÉG A VESZPRÉM-BALATON 2023 EURÓPA KULTURÁLIS FÖVÁROSA PROJEKT RENDEZVÉNYEIN. Turisztikai és Vidékfejlesztési Tanulmányok 2021 VI. évfolyam 1. szám, pp. 5-19

RAPORT NA TEMAT SYTUACJI OSÓB STARSZYCH W POLSCE (2012): Instytut Pracy i Spraw Socjalnych, Warszawa

ROBERSON, D. N. (2001): "The Impact of Travel on Older Adults: An Exploratory Investigation", Tourism, Vol. 49 No. 2, pp. 99-108.

ROBERSON, D. N. (2003): "Learning experiences of senior travellers", Studies in Continuing Education, Vol. 25 No. 1, pp. 125-144.

ROZPORZĄDZENIE MINISTRA INFRASTRUKTURY (2015): z dnia 12 kwietnia $2002 \mathrm{r}$. w sprawie warunków technicznych, jakim powinny odpowiadać budynki i ich usytuowanie. Dz.U.2015.1422 z dnia 2015.09.18 ze zm. 
RZEPKO, M. - DROZD, M. - DROZD, S. - BAJOREK, S. - KUNYSZ, P. (2017): “Uczestnictwo w turystyce i rekreacji ruchowej osób starszych - mieszkańców Rzeszowa", Handel Wewnętrzny, Vol. 2 No. 4, pp. 206-219.

ŚNIADEK, J. (2006): “Age of Seniors - A Challenge for Tourism and Leisure Industry”, Studies in Physical Culture and Tourism, Vol. 13, pp. 103-105.

ŚNIADEK, J. - ZAJADACZ, A. (2010): Senior citizens and their leisure activity - understanding leisure behaviour of elderly people in Poland. [In:] Studies in Physical Cultures and Tourism Vol. 17, No. 2, 2010: 193-204.

TRACZ-DRAL, J. (2019): Aktywność Osób Starszych, Kancelaria Senatu. Biuro analiz, dokumentacji i korespondencji. Warszawa. available at: https://www.senat.gov.pl/gfx/senat/pl/senatopracowania/170/plik/ot-672.pdf

UNWTO (2018): Messages of the World Committee on Tourism Ethics on Accessible Tourism

available at: http://cf.cdn.unwto.org/sites/all/files/docpdf/wctemessagesonaccessibletourism.pdf.

VISIT ENGLAND (2014): National Accessible Scheme For Serviced, Self-Catering, Hostel and Campus Accommodation) available at: https://www.visitbritain.org/sites/default/files/vbcorporate/visitengland_national_accessible_scheme_serviced_standards.pdf

VISIT ENGLAND (2014): 30-58, 68-85. National Accessible Scheme For Holiday, Touring \& Camping Parks and Caravan Holiday Homes, available at: file:///C:/AppData/Local/Temp/visitengland_national_accessible_scheme_holiday_parks_standar ds-2019.pdf

VIGOLO, V. (2017): Older Tourist Behavior and Marketing Tools, Springer International Publishing, Cham, available at: https://doi.org/10.1007/978-3-319-47735-0.

WEISS, R. (2019): "Conclusion", The Experience of Retirement, available at: https://doi.org/10.7591/9781501711725-011.

ZAJADACZ, A. (2014): “Dostępność przestrzeni turystycznej w ujęciu geograficznym”, Turyzm, Vol. 24, No.1, pp. 49-55.

ZAJADACZ, A. (red.) (2021): Zmiany w budzecie czasu wolnego i zachowaniach wolnoczasowych mieszkańców dużch miast $w$ wyniku pandemii COVID-19. Seria Turystyka i rekreacja - Studia i Prace t. 23. Bogucki Wydawnictwo Naukowe, Poznań. s. 1-152.

ZAJADACZ, A. - STROIK, E. (2016), Podstawy planowania rozwoju ,turystyki dostępnej, Uwarunkowania i plany rozwoju turystyki. Spoleczno-ekonomiczne problemy rozwoju turystyki, Vol. 16, pp. 65-83.

\section{Acknowledgments}

This work was supported by the project: "Research on COVID-19" from the funds of the University of Adam Mickiewicz in Poznań for the years 2020-2021, grant manager: Alina Zajadacz. 